\title{
The adaptation of MAIN to Icelandic
}

\section{Hrafnhildur Ragnarsdóttir}

University of Iceland

Immigration in Iceland has a short history and so does the Icelandic language as an L2. This paper gives a brief introductory overview of this history and of some characteristics of the Icelandic language that constitute a challenge for L2 learners but also make it an interesting testing ground for cross-linguistic comparisons of L1 and L2 language acquisition. It then describes the adaptation process of the Multilingual Assessment Instrument for Narratives (LITMUS-MAIN) to Icelandic. The Icelandic MAIN is expected to fill a gap in available assessment tools for multilingual Icelandic speaking children.

\section{Introduction}

Iceland is an island in The North Atlantic, with a population of a $364,000^{1}$ and an area of $103,000 \mathrm{~km}^{2}$, making it the most sparsely populated country in Europe. Two thirds of the population live in the greater capital area while the remaining one third are more dispersed and live in small towns, villages and farms along the coastline, the center of the country consisting of uninhabitable lava fields, glaciers and mountains. The official language is Icelandic, a Germanic language closely related to the other Nordic languages, Danish, Faroese, Norwegian and Swedish. The compulsory school age is from six to 16 years, but virtually all children attend municipal preschools from age two.

Until the turn of the Millennium, the population of Iceland was very homogeneous with few immigrants, few second language speakers of Icelandic and very few non-native children in Icelandic schools. Since then, the situation has changed radically with a rapid increase in number of immigrants with diverse cultural and linguistic backgrounds and an explosion in the number of children with other mother tongues than Icelandic in Icelandic schools, creating an important challenge for the educational system.

In this paper, I first briefly describe the Icelandic language, focusing on a few characteristics that may present a challenge for second language learners (Section 1.1). The second subsection is concerned with the history of immigration in Iceland (Section 1.2) and of

\footnotetext{
${ }^{11}$ Statistics Iceland, retrieved 16 March 2020.
} 
the short history of Icelandic as a second language (Section 1.3), after which the adaptation process of the Language Impairment Testing in Multilingual Settings-Multilingual Assessment Instrument for Narratives (LITMUS-MAIN, hereafter MAIN; Gagarina et al., 2012, 2019) to Icelandic is described (Section 2). Finally, some concluding remarks are presented (Section 3).

\subsection{The Icelandic language}

Icelandic is a Germanic language like English, for example. It is closely related to Danish, Faroese, Norwegian and Swedish with which it shares etymological roots and many cognate words. On the other hand, Icelandic differs from these languages in its morphological richness and complexity. Whereas English has a relatively simple inflectional morphology and the three Mainland Scandinavian languages are only slightly more complex, Icelandic (and for the most part also Faroese) has a rich and complex inflectional morphology involving a great variety of suffixes, stem changes and irregularities which tend to constitute a challenge for second language learners, especially those who have morphologically simple mother tongues. The following is a list of some of those characteristics:

- Nouns, adjectives, pronouns, the definite article (Icelandic does not have an indefinite article) and the numbers zero to four are all inflected in four cases: nominative, accusative, dative, genitive.

- Nouns, adjectives, pronouns and articles have singular and plural inflections,

- Adjectives, pronouns, articles and numbers (0 to 4) have a three-partite grammatical gender marking: masculine, feminine and neuter.

- Adjectives have inflection for comparison.

- Verbs are inflected for person, number, mood, tense and voice, yielding a minimum of 18 (weak verbs) and a maximum of over 40 (strong verbs) different forms of each verb. In comparison, English has a maximum of four different forms per verb and Danish, Norwegian and Swedish have seven.

Due to general morphophonological processes, vowel changes are common in all these paradigms. For instance, /a/ changes to / $\varnothing /$ when the inflectional ending in the following syllable starts with an /y/. As a result, in Icelandic, inflections change most words systematically all the time. For illustrative purposes, Table 1 shows the case inflection of the plural forms for the noun köttur 'cat' (plural kettir), the adjective svartur 'black' (plural svartir) and number prír 'three' in Icelandic as compared to English. 
Table 1. The inflection of three black cats in Icelandic vs/ English.

\begin{tabular}{llll}
\hline & $\begin{array}{c}\text { Icelandic } \\
\text { (masculine, plural) }\end{array}$ & \multicolumn{2}{c}{$\begin{array}{l}\text { English } \\
\text { (plural) }\end{array}$} \\
\hline Nominative & prír svartir kettir & (Here are) & three black cats \\
\hline Accusative & prjá svarta ketti & (I see) & three black cats \\
\hline Dative & premur svörtum köttum & (I lost) & three black cats \\
\hline Genitive & priggja svartra katta & (I miss) & three black cats \\
\hline
\end{tabular}

The noun köttur 'cat' has a masculine gender in Icelandic and accordingly the forms of the adjective and the number are also in their masculine (plural) forms in Table 1. The feminine (plural) form of 'three black' is prjár svartar in the nominative and the nominative (plural) for the neuter gender is prjú svört.

Table 2 presents the inflectional paradigm for the verb brjota 'break'. In addition to the forms in the table, the verbs also has the following additional forms: brjóttu (imperative singular), brjótið(i) (imperative plural), brotinn/brotin/brotið (past participle) and brjótandi (present participle), totalling 23 different forms and including six stem vowels: ó /ou/ - o / $/$ ý $/ \mathrm{i} / \mathrm{c}-\mathrm{au} /$ $/ \mathrm{i}-\mathrm{u} / \mathrm{Y} /-\mathrm{y} / \mathrm{I} /$.

Table 2: The paradigm for the verb brjóta 'break'.

\begin{tabular}{|c|c|c|c|c|}
\hline & $\begin{array}{l}\text { Present tense } \\
\text { indicative }\end{array}$ & $\begin{array}{l}\text { Past tense } \\
\text { indicative }\end{array}$ & $\begin{array}{l}\text { Present tense } \\
\text { subjunctive }\end{array}$ & $\begin{array}{l}\text { Past tense } \\
\text { subjunctive }\end{array}$ \\
\hline É $\boldsymbol{g}$ 'I' (1.sg.) & brýt & braut & brjóti & bryti \\
\hline Pú 'you' (2.sg.) & brýtur & braust & brjótir & brytir \\
\hline $\begin{array}{l}\text { Hann/hún/bað } \\
\text { 'he/she/it' } \\
\text { (3.sg.masc/fem/neut) }\end{array}$ & brýtur & braut & brjóti & bryti \\
\hline Vid ‘we' (1.pl.) & brjótum & brutum & brjótum & brytum \\
\hline Бið 'you' (2.pl.] & brjótið & brutud & brjótið & brytud \\
\hline $\begin{array}{l}\text { Peir/bar/pau 'they' } \\
\text { (3.pl.masc/fem/neuter) }\end{array}$ & brjóta & brutu & brjóti & brytu \\
\hline
\end{tabular}

Another typical linguistic feature of Icelandic is the relative frequency of long and complex consonant clusters at the beginning, in the middle and at the end of words (e.g. strjúka 'caress', öskra 'scream', smyrsl 'salve'). The pronunciation of these clusters is quite challenging for young children and second language learners. Finally, Icelandic has a very productive system for compounding, which together with all the inflectional suffixes results in longer words, on average, than for example in English and Swedish (Strömqvist, Johanson \& Ragnarsdóttir, 2002). Icelandic is an SVO language, but, due to case marking, its word order is very flexible. There are no dialects in Icelandic but some sounds have a slighly different pronunciation in different regions. 


\subsection{Immigration in Iceland}

Immigration in Iceland has a short history. Until recently, the population was very homogeneous with few immigrants and few speakers of Icelandic as a second language. In 1998, people of foreign origin comprised $2.5 \%$ of the population. They were almost exclusively Northern-Europeans adults who lived in the country for professional reasons and spoke English or Danish with the natives. Less than $1 \%$ were children and youth under the age of 17 . The last two decades have seen a radical change in this scenario with an increasingly steep growth in immigration in general, as shown in Figure 1, and a corresponding increase in the number of children with one or both parents of foreign origin (Table 3).

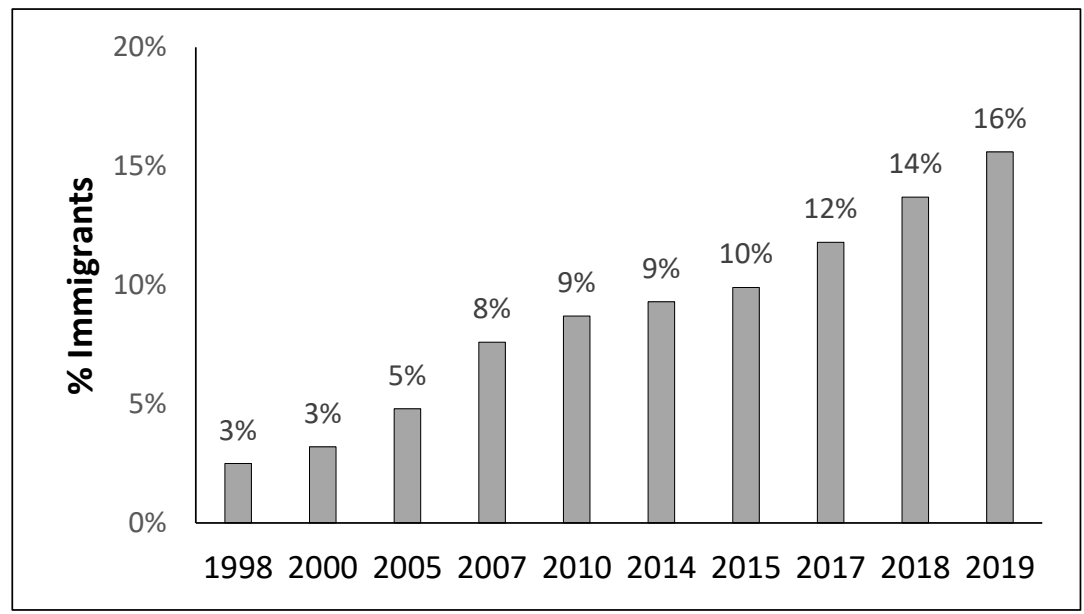

Figure 1: Immigrants (1st and 2nd generation) in Iceland 1998-2019: Percentages of the total population. (Statistics Iceland, 2020).

Table 3: Bilingual children in Iceland age 0 to 17 by year and background. Percentages of all children. (Statistics Iceland, 2020)

\begin{tabular}{lcccccc}
\hline & $\mathbf{1 9 9 8}$ & $\mathbf{2 0 0 0}$ & $\mathbf{2 0 0 5}$ & $\mathbf{2 0 1 0}$ & $\mathbf{2 0 1 5}$ & $\mathbf{2 0 1 7}$ \\
\hline $\begin{array}{l}\text { Children of 1st and 2nd generation } \\
\text { immigrants }\end{array}$ & $0.8 \%$ & $1.1 \%$ & $2.3 \%$ & $5.5 \%$ & $7.2 \%$ & $8.2 \%$ \\
\hline Mixed: one non-native parent & $6.0 \%$ & $6.6 \%$ & $7.9 \%$ & $9.5 \%$ & $10.8 \%$ & $11.3 \%$ \\
\hline All bilingual children & $\mathbf{6 . 6 \%}$ & $\mathbf{7 . 7 \%}$ & $\mathbf{1 0 . 2 \%}$ & $\mathbf{1 5 \%}$ & $\mathbf{1 8 \%}$ & $\mathbf{1 9 . 5 \%}$ \\
\hline
\end{tabular}

Figure 1 shows that first and second generation immigrants to Iceland progressed from $2.5 \%$ in 1998 to $15.6 \%$ in 2019, and Table 3 that between 1998 and 2017 the number of immigrant children increased by tenfold (from $0.8 \%$ to $8.2 \%$ ) and children having one non-Icelandic parent from $6 \%$ to $11.3 \%$. The total number of children with other mother tongues than Icelandic thus tripled between 1998 (6.8\%) and 2017 (19.6\%). The official counts of L2 children for 2018 and 2019 are not yet available but taking into consideration that the total percentage of immigrants increased by $3.6 \%$ from 2017 to 2019 (Figure 1), the share of L2 children has predictably risen to well over $20 \%$ since 2017.

In contrast to Denmark, Norway and Sweden, the larger majority of all immigrants in Iceland are first generation immigrants and the percentage of L2 children considerably higher 
in preschools than in primary and secondary schools. In the greater capital area, $24 \%$ of preschool children were bi- or multilingual in the spring 2018 and $17 \%$ of primary and secondary school children in autumn 2019. The number of different languages represented in Icelandic schools is well over 100. The largest language group by far is Polish which is the first language of $5.8 \%$ of all children in preschools and $4 \%$ in primary and secondary schools. Other relatively large language groups are Philippian, Vietnamese, Russian, English, Lithuanian and Spanish, each spoken by around $1 \%$ of all children (City of Reykjavik, n.d.).

\subsection{The context of L2 learning in Iceland}

Living in a multilingual society is a relatively new experience in Iceland. The recent and rapid increase in the number and variety of immigrants described in the section above, in particular non-native children in Icelandic schools, constitutes a real challenge to the educational system.

In the beginning there was, for obvious reasons, a lack of expertise in bi-/multilingualism and in the teaching of Icelandic as an L2. There was very little specific training for teachers in the instruction of non-native students and no mandatory courses for students graduating with M.Ed. as preschool or primary/secondary school teachers in subjects such as Icelandic as an L2, bilingual or multicultural education. This context has changed radically over the last years and the integration of children from diverse cultural and linguistic backgrounds and teaching them Icelandic in the process is now one of the country's main educational goals. Although there is still a long way to go, expertise in teaching Icelandic as an L2 to children and adults has taken a leap forward and multicultural policy is being adopted adopted for preschool, compulsory schools and after-school activities.

Practically all adult Icelanders speak English fluently. Therefore, adults from different cultural backgrounds who speak English can get by in the workplace and in their daily lives without learning Icelandic. For children, on the other hand, learning Icelandic is vital. All teaching in Icelandic schools is in Icelandic and in order to benefit from the Icelandic educational system they need to be proficient in spoken and written Icelandic. This is a challenging task, given some of the linguistic features of Icelandic described briefly above. For example, non-native four- and five-year-old preschool children in Reykjavík turned out to be far behind their native peers in vocabulary and even more so in morphology (Haraldsdóttir, 2013). Furthermore, research shows that L2 children continue to make limited progress in the acquisition of Icelandic vocabulary throughout their compulsory education (Thordardottir \& Juliusdottir, 2013; Ólafsdóttir \& Ragnarsdóttir, 2010) and that they lag significantly behind their L1 peers in reading comprehension (Ólafsdóttir, 2015) as well as on PISA (PISA, 2018). The acquisition of Icelandic as an L2 appears to occur at a slower rate than the L2 acquisition of English. In addition to the grammatical complexity of Icelandic, this is likely to be related to the low economic value of the latter (Thordardottir \& Juliusdottir, 2013).

To reach Iceland's educational goals, there is an urgently felt need for research-informed methods and structured materials both for instruction in Icelandic as an L2 and for supporting children's heritage languages, on the one hand, and for appropriate assessment tools for language and literacy development in both/all their languages from early childhood onwards on 
the other. To date, MAIN has been adapted for over 60 languages. The addition of the Icelandic MAIN will make an important contribution to filling the gap in assessment tools for L2 children in Iceland as well as for bilingual Icelandic children living abroad. It will also, more generally, be useful for the assessment of three to nine-year-old Icelandic children's overall language proficiency.

\section{The adaptation of MAIN to Icelandic}

The revised (2020) Icelandic MAIN was translated and adapted from the revised English version (Gagarina et al., 2019) following the guidelines for adapting MAIN to other languages (Bohnacker \& Gagarina, 2019). The translation was carried out by Hrafnhildur Ragnarsdóttir and carefully checked and compared to the English version (2019) by Rannveig Oddsdóttir. Ragnarsdóttir is professor of developmental science at the University of Iceland who has been engaged in research on most aspects of Icelandic children's language acquisition for over thirty years, including cross-linguistic studies of inflectional morphology and narratives (see e.g. (Ragnarsdóttir, Simonsen \& Plunkett, 1999; Ragnarsdóttir 1992; 1999). Oddsdóttir is assistant professor of early childhood language and literacy at the University of Akureyri. Her primary research focus is early writing development.

This final revised 2020 version of the Icelandic MAIN builds on two earlier translations. In 2012, the Baby Birds Story was translated into Icelandic by Ragnarsdóttir, who also wrote instructions for its use based on those of Gagarina et al. (2012). This first version was used in M.Ed. courses on language and literacy development at the University of Iceland. The students, majoring in early childhood language and literacy development, were required to assess the language proficiency of native Icelandic children and to compare mono- and bilingual children in Icelandic pre- and elementary schools, using MAIN as well as other measures. The story and the instructions were extensively piloted with these students and subsequently used with 120 five- and six-year-old monolingual Icelandic children participating in a longitudinal research project, Development in Early Childhood: Language, literacy and self-regulation. The first version was subsequently revised (2015) by Ragnarsdóttir, Oddsdóttir and Elva Dögg Gunnarsdóttir, an M.Ed. student who made an important contribution to the adaptation and piloting of both earlier versions of the Icelandic MAIN.

Having a mother tongue with less than 400 thousand speakers, Icelandic children are used to books, films, TV programs and other material in, or translated from, other languages and cultures. Although the characters and contexts in the four MAIN picture stories were not all familiar, they therefore did not seem to present any major problems for the children.

The translation of the model stories from English to Icelandic was also mostly straightforward. In a few cases, however, a translation equivalence was not available and a direct translation was substituted with words and expressions which better fitted the context, the overall flow in the story and/or the language level of children in the targeted age-range. Thus, for example, the adjectives playful and the verb grab do not have directly matching words in Icelandic. Instead, functionally equivalent words were used, i.e. fjörugur 'lively, merry, 
vibrant, playful' for playful and, depending on the context, grab was translated as ná $i$ ' $\approx$ get, catch' in the Baby Bird story or by using a more specific word, bita 'bite', in the Dog story. Possessive pronouns are more frequently used in English than in Icelandic and were omitted when they seemed redundant.

All four stories start with the expression One day... in English. The literal translation sounds somewhat formal and awkward in this context in Icelandic and was therefore translated with pað var einu sinni 'it was once' or einu sinni var 'once (there) was.' Other examples of differences include inserting a relative clause, as in (1) and (2):

Mmm, nice, what do I see here in the nest?

Icelandic: Mmm, dásamlegt, hvað er pað sem ég sé í hreiðrinu?

[Literal translation: Mmm, lovely, what is it that I see in the nest?]

(2) Meanwhile, the cat noticed the boy's bucket and thought: I want to grab a fish.

Icelandic: Á meðan tók kötturinn eftir fötunni sem strákurinn var með og hugsaði með sér: ég aetla að ná mér í fisk í matinn.

[Literal translation: Meanwhile, the cat noticed the bucket that the boy was holding and thought: I am going to get myself a fish to eat.]

Finally, although Icelandic does have non-finite clauses, in a few cases complement clauses were used instead because they are more frequent in colloquial language and in child-directed speech. For example, He looked at the cat chasing the butterfly was translated as Hann sá að kötturinn var að elta fiðrildið 'He saw that the cat was chasing the butterfly.'

\section{Concluding remarks}

Living in a multicultural and multilingual society is a relatively new experience in Iceland. Until recently, the population was homogeneous and non-native speakers of Icelandic extremely rare. Over the last two decades, however, this scenery has changed radically with, in particular, an explosion in the number and variety of L2 children in Icelandic schools.

Icelandic is the only official language in Iceland and all instruction in Icelandic schools takes place in Icelandic. In a relatively short time, integrating children from different cultures and linguistic backgrounds and teaching them Icelandic to enable them to benefit from the Icelandic educational system, has become an educational priority. Multicultural policy has been adopted for all school levels and after-school activities. Although expertise in teaching Icelandic as an L2 has taken a leap forward, it still constitutes a real challenge for teachers and other educators. There is an urgent need for research on Icelandic as an L2, for evidence-based teaching methods and for appropriate assessment tools for language and literacy development in both/all children's languages from early childhood onwards. The purpose of the Icelandic MAIN is, firstly, to contribute to filling the gap in assessment tools for L2 children in Iceland as well as for bi- and multilingual Icelandic children living abroad. It will also, more generally, be useful for the assessment of three to nine-year-old Icelandic children's overall language 
proficiency. Finally, the fact that this common assessment instrument can be used to study the language development of children's learning over sixty different languages, opens up a wealth of interesting research possibilities. To mention just a couple of examples, comparing the L2 development of Polish immigrant children in Iceland on the one hand and in England on the other, could shed light on the importance of the global status of the L2 language for children's acquisition process since, contrary to learning a lingua franca like English, the benefit of learning Icelandic is limited to Iceland. Another example of a research question inspired by the Icelandic context could concern the role of the grammatical characteristics of the L2: What does immigrant children's acquisition of two closely related languages such as Icelandic and Norwegian (or Danish or Swedish) reveal about the role of morphological complextity of the L2 language to be learned?

\section{$4 \quad$ Acknowledgments}

This work was in part supported by grant \#080648021 from RANNIS (Icelandic Centre for Research). Many thanks to Rannveig Oddsdóttir, Elva Dögg Gunnarsdóttir, Árdís Hrönn Jónsdóttir and other assistants. Thanks also to Fríða B. Jónsdóttir, Kristín Mar, Josefin Lindgren and Natalia Gagarina for helpful comments on this chapter.

\section{$5 \quad$ References}

Berman, R. A. \& Slobin, D. I. (Eds.). (1994). Relating events in narrative: A crosslinguistic developmental study. Hillsdale, New Jersey/Hove, UK.: Lawrence Erlbaum Associates.

Bohnacker, U. \& Gagarina, N. (2019). Background on MAIN - Revised, how to use it and adapt it to other languages. ZAS Papers in Linguistics, 63, iv-xii.

City of Reykjavik (n.d.). Overview of the languages spoken in Reykjavik. Downloaded from: https://reykjavik.is/sites/default/files/skjol_borgarstjornarfundur/tillogur_og_greinargerdir_fjolmenninga rrads.pdf

Gagarina, N., Klop, D., Kunnari, S., Tantele, K., Välimaa, T., Balčiūniené, U. \& Walters, J. (2012). MAIN: Multilingual Assessment Instrument for Narratives. ZAS Papers in Linguistics, 56.

Gagarina, N., Klop, D., Kunnari, S., Tantele, K., Välimaa, T., Bohnacker, U. \& Walters, J. (2019). MAIN: Multilingual Assessment Instrument for Narratives. Revised version. ZAS Papers in Linguistics, 63.

Haraldsdóttir, H. P. (2013). Pátíðarmyndun og stæerð íslensks orðaforða tvítyngdra leikskólabarna. [Bilingual preschool children's past tense inflections and size of Icelandic vocabulary]. M.Ed. thesis. Háskóli Íslands, Reykjavík.

Ólafsdóttir, S. (2015). The development of vocabulary and reading comprehension among Icelandic second language learners [Próun orðaforða og lesskilnings íslenskra grunnskólanema sem hafa annað móðurmál en íslensku]. (Ph.D.). University of Iceland, Reykjavík. 
Ólafsdóttir, S. \& Ragnarsdóttir, H. (2010). Íslenskur orðaforði íslenskra grunnskólanema sem eiga annað móðurmál en íslensku [The Icelandic vocabulary of L2 children in Icelandic primary schools]. Menntakvika, Netla. doi: http://hdl.handle.net/1946/4612.

Programme for International Student Assessment (PISA) (2018). Results for PISA 2018, Iceland: http://www.oecd.org/pisa/publications/PISA2018_CN_ISL.pdf

Ragnarsdóttir, H. (2004). Málproski barna við upphaf skólagöngu: Sögubygging og samloðun í frásögnum 165 fimm ára barna - almenn einkenni og einstaklingsmunur [Language development at schoolstart: Story structure and cohesion in 165 Icelandic five-year-olds' narratives]. Uppeldi og menntun, 13(2), 9-31.

Ragnarsdóttir, H., Simonsen, H. G. \& Plunkett, K. (1999). The acquisition of past tense morphology in Icelandic and Norwegian children: an experimental study. Journal of child language, 26(3), 577-618.

Ragnarsdóttir, H. (1992). Episodic structure and interclausal connectives in Icelandic children's narratives. In R. Söderbergh, (Eds.), Berättelser för och av barn. Colloquium Paedo-linguisticum Lundensis 1991 (pp. 3345). Lund University: Department of Linguistics.

Statistics Iceland (2020). Information about the proportions of immigrants and bilingual children from 1998 to 2019/2017. Accessed on 16 March 2020.

Strömqvist, S., Johanson, V., \& Ragnarsdóttir, H. (2002). Toward a crosslinguistic comparison of lexical quanta in speech and writing. Written Language and Literacy, 5(1), 45-67.

Thordardottir, E. T., \& Juliusdottir, A. G. (2013). Icelandic as a second language: a longitudinal study of language knowledge and processing by school-age children. International Journal of Bilingual Education and Bilingualism, 16(4), 411-435. 